\author{
Ana Kotevska* \\ Serbian Musicological Society \\ Belgrade
}

\title{
SERBIAN MUSICOLOGICAL SOCIETY AT THE BEGINNING OF ITS SECOND DECADE (2006-2017)
}

\begin{abstract}
The purpose of the text is to present, on the occasion of the $10^{\text {th }}$ anniversary of the establishment of the Serbian Musicological Society (SMS), the circumstances of its founding on 5 July 2006 and offer a panoramic survey of its accomplishments in research and publishing so far, which re-examine our stance toward our musical heritage and/or illuminate previously neglected chapters from the history of music in Serbia. The many and diverse contributions of the Serbian Musicological Society to the achievements of Serbian musicology in general are reflected in its conception and organization of scholarly meetings, publication of essay collections, scores, and sound recordings, organization of concerts, as well as initiation of large-scale projects in the reconstruction of individual anthological works of stage music, independently and in collaboration with related institutions and opera houses.
\end{abstract}

Keywords: Serbian Musicological Society; publishing; essay collections; anthological works; Serbian music history; partnering

* The author has served as President of the Serbian Musicological Society since 2013; Author contact information: ana.kotevska18@gmail.com 
Marking the $10^{\text {th }}$ anniversary of Serbian musicologists from various generations and professional orientations coming together to invest their creative energy, knowledge, and communication, this presentation of their Society should in itself be the expression and result of their shared positions, overall. Therefore, one should relativize the authorial attribution of this text that appears at the top of the page, an attempt at a retrospective, introspective, and perspectival overview of the Serbian Musicological Society's first decade, and read the lines that follow as an initial polyphonic material for future explorations, open to additions, corrections, and fresh views and revalorizations of the Society's achievements.

The $10^{\text {th }}$ anniversary of the founding of the Serbian Musicological Society (SMS $)^{1}$ is an occasion and obligation to look back on its journey so far, but it offers no special reason for uncritical complacency, since the history of European music historians forming their first professional associations begins already in the $1860 \mathrm{~s}$, first in Holland in 1868 , then, six years later, ${ }^{2}$ in Great Britain, with existing national chapters forming their first umbrella organization already in $1894 .{ }^{3}$ Also, the establishment of musicological societies in Croatia and Slovenia in 1992, during the breakup of Yugoslavia, which we shared as our common country at the time, and, five years later, in Bosnia and Herzegovina as well, ${ }^{4}$ makes one wonder why "local" musicologists (first in Yugoslavia and then, following its collapse, in Serbia) were so late in joining the family of related scholarly associations. One explanation should be sought in the fact that the Composers' Association of Serbia (CAS), founded in 1945 as a result of the implementation of ideological cultural models borrowed from the Soviet Union, ${ }^{5}$ established its Music Writers' Section already the following year, as a broad fo-

\footnotetext{
${ }^{1}$ The Society was founded on 5 July 2006 and registered on 7 January 2007 at No. 1a, Trg Nikole Pašića, Belgrade, the offices of the Music Information Centre of Sokoj (Serbian Music Authors' Organization). When the Centre closed down in 2009, the Society moved to the offices of the Composers' Association of Serbia at Mišarska, Nos. 12-14, Belgrade. smusicologicalsociety@gmail.com; https://sr-rs.facebook.com/serbianmusicologicalsociety.

${ }^{2}$ The (Royal) Society for Music History of the Netherlands (VNU), 1868; Royal Musical Association (RMA), 1874; Gesellschaft für Musikforschung (GfM), 1946; Société Française de musicologie, 1917; American Musicological Society, 1934.

3 The International Music Society was founded in 1898, but had to suspend its ativities in 1914; it was reactivated in 1927, under a new name - International Musicological Society.

${ }^{4}$ The Croatian Musicological Society and the Slovene Musicological Society were founded in 1992; the Musicological Society of the Federation of Bosnia and Herzegovina was established in 1997.

5 The Union of Soviet Composers and Musicologists was founded in 1932; the Union of Composers and Musicologists of the Russian Socialist Federal Soviet Republic was founded as its asignee in 1960, renamed in 1990 the Union of Composers and Musicologists of the Russian Federation.
} 
Kotevska, A., Serbian Musicological Society at the Beginning of its Second Decade

rum for musicologists and ethnomusicologists as well as all those who participated in Serbia's musical life by means of the media. ${ }^{6}$ For most of its members, this Section, especially after Yugoslavia's rejection of Soviet policies and accelerated processes of liberalization in Yugoslavia's cultural sphere, apparently provided a satisfactory and sufficiently stimulating framework for their work and secured an equal status for musicologists as well as proximity and close collaboration with ethnomusicologists and especially composers. It will suffice to mention that Article 1 of the Composers' Association's Statute, in addition to the "affirmation of valuable works of art", also emphasizes the "affirmation of scholarly, expert, and published studies, texts, and broadcasts". ${ }^{7}$ Also, one should bear in mind that, as an integral component of the Union of Composers' Associations of Yugoslavia (SOKOJ), the members of the Musical Writers' and Musicologists' Section had the opportunity to keep abreast of and take an active part in events across the former Yugoslavia and thus benefit from open channels of collaboration and discussion, admittedly not always smooth or productive, with colleagues from other Yugoslav republics, as well as from other countries, with which SOKOJ had established cooperation.

The dramatic historical changes of the early 1990s, following the disappearance of Yugoslavia, which Serbia officially sought to succeed as its sole legitimate successor state, years of war and hardship, international sanctions and thus also the severing and/or dying out of cultural ties conditioned painful structural and other changes in the cultural life of Belgrade (above all due to a large number of quality musicians moving abroad and the weakening of cultural institutions), but also contributed to the cohesion of most of the remaining members of the Composers' Association, ${ }^{8}$ who concentrated on reorganizing, adjusting to the new reality, and striving to preserve the vitality and dignity of the profession by means of new projects, conceived on new grounds, such as the International Review of Composers ${ }^{9}$ and the New Sound: International Journal of Music, ${ }^{10}$ which today constitute relevant driving forces in Serbia's contemporary musical creativity, with an international prefix. Looking back from a historical distance spanning a quarter of a century, one might say that having to invest energy into

\footnotetext{
${ }^{6}$ See: www.composers.rs / History, 363.

7 Ibid

${ }^{8}$ Unlike some other associations, during the 1990 s, on several occasions, the Composers' Association of Serbia protested against the belligerent policies of the Serbian leadership at the time, against hate speech, nationalist and closed cultural policies, and lent its support to students' protests.

${ }^{9}$ The first International Review of Composers was held in 1992.

${ }^{10}$ Novi zvuk/New Sound International Journal of Music first came out in 1993 as a biannual periodical in Serbian and English.
} 
solving these hierarchically urgent matters probably further delayed the founding of the Serbian Musicological Society, although even then, in spite of difficult political and social circumstances, hostile to theoretical considerations, the circle of Serbian musicologists was already acting as a dynamic common group, expanding its membership and striving to renew its contacts and remain in touch with new developments in the world of musicology.

Without, on this occasion, going into other possible reasons for the belated founding of the Society, ${ }^{11}$ we may conclude today that the idea and need to create an autonomous scholarly and professional platform for musicologists in Serbia finally matured in 2006, after reaching a consensus about its aims and directions, without preventing its members from retaining their membership in the Music Writers, Musicologists, and Ethnomusicologists' Section of the Composers' Association of Serbia.

The constitutive assembly of the Serbian Musicological Society elected Dr Mirjana Veselinović Hofman as its first president, who at the time served as Chair of the Musicology Department of the Faculty of Music, editor-in-chief of the New Sound musicology journal, and initiator of this musicological association; Dr Melita Milin, a research fellow at the Institute of Musicology of the Serbian Academy of Sciences and Arts, was elected vice-president; finally, the assembly also elected members of its Steering Committee, ${ }^{12}$ to five-year terms.

On that occasion, the main aims of the Society were enshrined in its Statute, remaining unchanged ever since: to develop and promote musicological creativity in Serbia and beyond; to publish, on a regular basis, an information bulletin about the Society's undertakings and media promotion of its activities; to organize concerts (focusing on Serbian musical creativity); to organize national

\footnotetext{
11 One should bear in mind that, in line with European legislation in this domain, SOKOJ was transformed from its erstwhile role as the Union of Composers' Associations of Yugoslavia into a business association with the exclusive purpose of protecting its members' intellectual rights and promoting or distributing their works. That was also the reason why Sokoj's Music Information Centre was gradually abolished, whose activities had also incorporated publishing, among other things (it was the original publisher of Novi zvuk).

${ }^{12}$ Apart from the president and vicepresident, the Society's first Steering Committee also comprised Dr Vesna Mikić, Dr Branka Radović, Dr Katarina Tomašević, Dr Ivana Perković Radak, and Biljana Milanović; in January 2013, a new team was appointed to run the Society (Ana Kotevska, MA, president; Dr Biljana Milanović, vicepresident; Dr Tijana Popović Mlađenović, Steering Committee chair; Dr Branka Radović, Dr Melita Milin, Dr Ivana Medić, and Milan Milojković, members of the Steering Committee). In 2016, Dr Marija Masnikosa was appointed Chair of the Steering Committee. During the Society's first decade, the running of its Secretariat was entrusted to three young musicologists: Dušanka Jelenković Vidović, Ivana Petković, and Jelena Janković Beguš.
} 
Kotevska, A., Serbian Musicological Society at the Beginning of its Second Decade

and international scholarly meetings; to pursue research projects; to organize scholarly or professional-informative lectures, thematic and discussion forums; to establish contacts and collaboration with foreign musicological associations and actively participate in the International Musicological Society; to engage in publishing activities.

The Society's guiding policy in forming those aims, which also constitute the platform for its activities in the future, rests on two premises stemming from the nature of the discipline itself, which are self-evident to the members of the Society but may be less so to the wider public. First: that musicology, as a multi-disciplinary field of study, pertains to creativity and creative contemplation of the art of music as its driving energy; second: that, in line with contemporary trends in new (critical) musicology, the domain of its potential explorations should expand beyond music qua written text, to encompass recorded sound, the art of interpretation, perception and reception, context and its variable aspects, that our positions regarding our heritage and established precepts should be constantly re-examined, developed, and modified.

According to the Statute of the Serbian Musicological Society, its members are or may be academic musicologists of various generations from Serbia and abroad who have actively and continuously pursued scholarly work in musicology, ethnomusicologists and theorists, as well as individual scholars from various disciplines, whose research involves, among other fields, that of music. Also, in line with the policies of related associations, established in the early $20^{\text {th }}$ century, one may say that the membership of the Serbian Musicological Society, while relatively small in comparison to related associations boasting of a longer tradition (in total, 55 full members from Serbia, Switzerland, Israel, Ireland...) $)^{13}$ covers a wide range of tendencies in musicology as an interdisciplinary science, which means that one may speak today of a dynamic inter-generational picture, ranging from classical music historiography, via systemic, new, and critical musicology, to cultural studies.

The Society's initial steps received an additional impulse with the name of Vlastimir Peričić (1927-2000), a renowned theorist, musicologist, and composer, whose contributions in pedagogy and scholarship, especially in the domain of Serbian music history, marked generations of musicologists. Namely, the fact that the legal successor of Vlastimir Peričić, Radivoj Lazić, entrusted a part of his legacy to the Society for safekeeping, imposed an additional obligation on its members to continue his tireless work in researching Serbian musical culture from its beginnings to the present and to keep uncovering its forgotten and lost pages. To mark what would have been Peričić's $80^{\text {th }}$ birthday, the Legacy

${ }^{13}$ As of 1 November 2017. There are ongoing discussions about admitting new candidates. 
Library of Vlastimir Peričić was inaugurated on 7 December 2007 at Sokoj's Music Information Centre, where it is still located,${ }^{14}$ and the following year saw the publication of the Catalogue to the Legacy Library of Vlastimir Peričić in Belgrade and Sarajevo. ${ }^{15}$

Symbolically marked in this way, the beginning of the Society's activities was soon followed by its first undertaking in publishing, which brought the Society into direct contact with the International Musicological Society, by way of its essay collection Musical Folklore as a Vehicle?, published in the run-up to the eponymous scholarly gathering. ${ }^{16}$ With this publication and conference, the Society also joined the activities of the Regional Association for the Study of Music in the Balkans, a chapter of the International Musicological Society.

The inauguration of the Legacy Library of Vlastimir Peričić already included a concert featuring his works, whereby the Society symbolically began implementing its fundamental stance - that interpreting and reinterpreting major works, in live performances and recordings, would form one of its constant preoccupations and research priorities.

This is also attested to by the launching of the project titled Anthological Pieces of Serbian Music, which, unfortunately, due to insufficient funding, ${ }^{17}$ had to be suspended after two concert events, which were then released as sound recordings, comprising performances of a selection of representative works of Serbian chamber music by renowned ensembles and soloists. ${ }^{18}$ Works by Stanojlo Rajičić (Lisje žuti/The Leaves are Turning Yellow, a cycle of pieces for baritone and piano); Ljubica Marić (Asimptota/Asymptote); Zoran Erić (Šest scena-komentara/Six Scene - Comments) for string quartet; string quartets by Petar Konjović (No. 2) and Josip Slavenski (No. 2); Dejan Despić's cycle Brankova Lira (Branko's Lyre) for mezzo-soprano and string quartet; and Ivana Stefanović's Play Strindberg provide a consistent testimony of the high creative achievements of three generations of composers and of new impulses that their

\footnotetext{
14 The remainder of Peričić's Legacy was given for safekeeping to the Academy of Music at the University of East Sarajevo.

${ }^{15}$ Katalog Legata Vlastimira Peričića u Beogradu i Sarajevu, Belgrade, Serbian Musicological Society, 2008. Edited by Sonja Marinković and Branka Radović.

${ }^{16}$ Musical Folklore as a Vehicle?, IMS, Serbian Musicological Society, Department of Musicology and Department of Ethnomusicology of the Faculty of Music, 2008.

17 Since it does not enjoy the status of a "representative artistic association", which means that it has no access to regular subsidizing, the Serbian Musicological Society is funded exclusively through projects and must rely on the volunteering and enthusiasm of its members. 18 Антологијска дела српске музике / Anthological Pieces of Serbian Music CD 1 (2009) and CD 2 (2010), Belgrade, P Signature Publishing, Serbian Musicological Society.
} 
works have acquired in encounters with representatives of the youngest generation of interpreters and musicological commentaries written by connoisseurs of individual oeuvres. Continuing this series, initiated with so much success, with new works that have meanwhile stood the test of time, from new angles of interpretation stemming from musicology and performance studies, seems like a logical and desirable project for the Serbian Musicological Society at the beginning of its second decade.

The Society's publishing activities, focused on developing and promoting musicological creativity as one of its chief aims, did not remain confined to paying homage to the professional, scholarly, and pedagogical work of Vlastimir Peričić, but also attempted to illuminate previously neglected aspects, and produce an overview from the perspective of contemporary trends in musicology, of the contributions of two doyens of Serbian (and, inevitably, Yugoslav) musicology: Stana Đurić Klajn (1908-1986) ${ }^{19}$ and Nikola Hercigonja (1911-2000), ${ }^{20}$ on the occasion of their respective centenaries. The first publication, comprising 14 contributions by musicologists from various generations and focused around two topics (S.Đ.K. as a writer on music and S.Đ.K. - editor, redactor, and pianist), actually constitutes the proceedings of the musicological conference held under the same title in December 2008, while the second volume, including 13 studies and texts, was an attempt to encompass various spheres of Hercigonja's work, such as composing (with emphasis on stage genres), views in musicology and music theory, and the invariably prominent social involvement of his music. Among these, especially productive were the contributions of our younger musicologists, who approach these important pioneers of Serbian musicology from a significant time distance.

Also, looking back at earlier chapters and figures who made Serbia's presently rich and diverse musicological scene possible, the Society did not forget the contributions of Pavle Stefanović (1901-1985) and Dragutin Gostuški (1923-1998) either, whose dynamic, often provocative writings, and colourful public interventions in audiovisual media often effected an increase in the visibility of musical and musicological creativity, enhanced knowledge, and influenced the tastes of the wider public.

Responding to a joint call by the Composers' Association, the Musicological Society, and the Department of Musicology at the Faculty of Music, more than 20 participants, including experts in contemporary music, fine arts, liter-

${ }^{19}$ Стана Бурић-Клајн и српска музикологија [Stana Đurić Klajn and Serbian Musicology], Београд, Музиколошко друштво Србије, 2010.

20 Никола Херцигоња (1911-2000) - Човек, дело време [Nikola Hercigonja (1911-2000)The Man, His Work and Time], Београд, Музиколошко друштво Србије, 2011. 
ature, theatre, and media work, came together in May 2016 for a rather stimulating multi-disciplinary scholarly conference dedicated to Pavle Stefanović, entitled "There is indeed accounting for Tastes". The contributions of this aesthetician, theorist, critic, radio artist and leftist author, librarian, occasional conductor of recital choirs, and actor, who always advocated the novum observed through the category of the judgement of taste, will receive special treatment in a forthcoming book of essays. Also, in a joint venture, the Serbian Musicological Society and the publishing arm of the Serbian Broadcasting Corporation (RTS) published a critical edition of Rađanje srpske muzičke kulture (The Birth of Serbian Musical Culture), ${ }^{21}$ one of the most successful TV series produced by the Educational Programming of Radio Television Belgrade in 1980s, written and presented by Dragutin Gostuški, a musicologist, aesthetician, composer, and one of the leading Serbian art critics in the latter half of the $20^{\text {th }}$ century. Complete with additional musicological studies about the author and TV history of Serbian music, commentaries from the perspective of contemporary insights, as well as a DVD edition of the entire series, this bilingual edition constitutes not only a tribute to a somewhat forgotten but authentic figure from Serbia's musical life, but also an attempt by the Serbian Musicological Society to expand its scholarly and research activities with more communicative interventions such as this one. ${ }^{22}$

Also, the Society has offered new readings of complete oeuvres and individual chapters from Serbian music history, with a critical view and from the viewpoint of contemporary insights, in two essay collections, focused on students of composition from the Kingdom of Yugoslavia who studied in Prague ${ }^{23}$ and on Predrag Milošević. ${ }^{24}$ The former book's 11 essays by Serbian and foreign musicologists about the "Prague students" offer new insights into their avant-garde

\footnotetext{
21 Драгутин Гостушки, Рађање српске музичке културе / Dragutin Gostuški, The Birth of Serbian Music Culture, Belgrade, Serbian Broadcasting Corporation, Serbian Musicological Society, 2017.

${ }^{22}$ Pursuing the same intent, the Society has also established cooperation with the Gymnasium of Valjevo, for whose students and professors the Musicological Society of Serbia organized concert lectures on Mokranjac and Ljubica Marić in November 2014 and March 2015.

23 Праг и студенти композииије из Кравевине Југославије - поводом 100. годиињице рођења Станојла Рајичића и др Војислава Вучковића [Prague and Students of Composition from the Kingdom of Yugoslavia - Celebrating the Centenary of Stanojlo Rajičić and Dr Vojislav Vučković], Београд, Музиколошко друштво Србије, 2010.

24 Многострука уметничка делатност Предрага Миломевића (1904-1988), поводом 110. годииьице рођена [The Manifold Artistic Activities of Predrag Milošević (19041988)], Београд, Музиколошко друштво Србије и Катедра за музикологију Факултета музичке уметности, 2015.
} 
Kotevska, A., Serbian Musicological Society at the Beginning of its Second Decade

ideas and modernist artistic interests, which they disseminated upon returning to their country, as well as different interpretations and responses, both accepting and otherwise, their ideological and artistic positions encountered, attesting to "a dynamic and challenging, as well as a rather complex, treacherous, and dangerous period in ideological and political terms". 25

A special feature of the second publication is the fact that it was initiated by the Department of Musicology at the Faculty of Music, following a successful panel held by fourth-year students of the Musicology Study Programme, on various aspects of the multifarious work of Predrag Miloševic, of whom otherwise very little has been written, and that it resulted from a scholarly meeting involving musicologists and composers of various generations (from Milošević's own contemporaries and students, expert connoisseurs of his oeuvre, to current students of musicology). Grouped in four thematic areas (Works, Activities in Belgrade's Musical Life, Memories, Looking at History), the contributions, according to the editor, Marija Masnikosa, "summed up Milošević's 'performance' in the domain of Serbian culture and highlighted the unquestionable significance of this author in Serbian music history". ${ }^{26}$

Since the Society's collaboration with the Musicology Department of the Faculty of Music on the organization of the conference and essay collection on Predrag Milošević proved so stimulating and useful for both institutions, assembling a large number of participants and encountering a favourable reception from the public, the Serbian Musicological Society continued to initiate various kinds of partnerships in its ensuing projects as well. A major impact was made by two publications marking the centenary of the death of Stevan Stojanovic Mokranjac (1856-1914), which, according to professional circles, made an original contribution to the study of less well known aspects of this outstanding author's work in composition and conducting, as well as his role in the cultural trends of his time.

The first project, initiated by two young musicologists, Ivana Petković and Olga Otašević, Стеван Стојановић Мокрањаи у написима „других” (Stevan Stojanović Mokranjac in the Writings of "Others"), ${ }^{27}$ was realized in coopera-

\footnotetext{
${ }_{25}$ Mirjana Veselinović Hofman, „Уводна реч“ [Foreword], IIраг и студенти композиције из Кравевине Југославије [Prague and Students of Composition from the Kingdom of Yugoslavia], op.cit., 9.

26 Уводна реч (Foreword) by the editor, Marija Masnikosa, Многострука уметничка делатност Предрага Миломевића, ор. cit., 12.

27 Ivana Petković and Olga Otašević, Стеван Стојановић Мокрањацу написима „других“ [Stevan Stojanovic Mokranjac in the Writings of "Others"], Београд, Музиколошко друштво Србије и Музичка омладина Београда, 2014.
} 
tion with the Musical Youth of Belgrade and used as the mandatory manual at the Musical Youth Quiz competition, which was dedicated that year to the great Serbian composer. In the four chapters of this composite, essentially postmodernist publication, ${ }^{28}$ the authors present their methodology, then Mokranjac's reception in writings by authors from Croatia, Slovenia, Bosnia and Herzegovina, Macedonia, and Montenegro, provide a complete Serbian translation of the 1958 study of Mokranjac and Serbian music by the Russian musicologist Ivan Martinov and contextualize it in relation to an impressive bibliography of writings about the composer, and finally, in the fourth chapter, present their own readings of various publications about Mokranjac in Russian, English, French, Italian, Bulgarian, and German.

Working on the second international project (Stevan Stojanovic Mokranjac: inostrane koncertne turneje sa Beogradskim pevačkim društvom - Stevan Stojanović Mokranjac: Foreign Concert Tours with the Belgrade Choral Society), ${ }^{29}$ authored by Biljana Milanović, was a new experience in collaborating with related institutions, this time with the Institute of Musicology at the Serbian Academy of Sciences and Arts, and another important achievement in the Society's publishing activities. In ten contributions by foreign and Serbian musicologists, the book provides what is so far the most comprehensive insight into the significance of the Belgrade Choral Society's foreign tours, points to new insights about Serbia's cultural diplomacy in Europe and the Balkans at the time, and implicitly attests to attempts to form a South Slavic, that is, Yugoslav cultural space in the domain of music, wherein today we can see the first signs of preparations for the formation of a common state. ${ }^{30}$ The special import of this

\footnotetext{
${ }^{28}$ See Marija Masnikosa, „Ivana Petković, Olga Otašević, Stevan Stojanović Mokranjac u napisima "drugih" [Stevan Stojanovic Mokranjac in the Writings of "Others"]", New Sound 44, II/2014, 211-214; Milica Gajić, „Два нова издања објављена поводом стогодишњице смрти С. Ст. Мокрањца" [Two New Editions Published on the Centenary of the Death of S. St. Mokranjac], Mokranjac, 16/2014, 30-32.

${ }^{29}$ Stevan Stojanović Mokranjac, The Belgrade Choral Society Foreign Concert Tours, Belgrade, Institute of Musicology of the Serbian Academy of Sciences and Arts and Serbian Musicological Society, 2014. This bilingual volume, published in Serbian and English, was included in the official programme to mark the centenary of the First World War, sponsored by the Ministry of Culture and Information of the Republic of Serbia.

${ }^{30}$ See Sonja Cvetković, "S.St. Mokranjac - the Belgrade Choral Society Foreign Concert Tours", New Sound 46, II/2015, 187-191; Marija Ćirić, "Музика као дипломатска стратегија" [Music as a Diplomatic Strategy], Srpski književni list 11/116/2015, 5; Dragana Stojanović Novičić, "С.Ст. Мокрањац, Иностране концертне турнеје са Београдским певачким друштвом" (S. St. Mokranjac: Foreign Tours with Belgrade Choral Society), Muzikologija, 19, 179-184.
} 
Kotevska, A., Serbian Musicological Society at the Beginning of its Second Decade

project stems from the fact that the authors of the contributions about the Belgrade Choral Society's performances and reception in Budapest, Sofia, Istanbul, Nizhny Novgorod, Berlin, Dresden and Leipzig, Thessaloniki, Skopje, Cetinje, Sarajevo, Mostar, Split, Šibenik, Zadar, and Trieste are by and large foreign musicologists, who in this way brought us closer to previously unknown archival materials, at the same time familiarizing themselves with an important episode from Serbian music history.

The project Od zapisa do zvuka (From Recording to Sound), aimed to "protect, preserve, and present immaterial cultural heritage [...] the realization of permanent (digital) audio recordings of works by Isidor Bajić, Krešimir Baranović, and Nikola Hercigonja, recorded on old magnetic tapes kept at the $\mathrm{Mu}-$ sic Faculty Library", invaluable recordings since they are the only preserved recordings of these works in performance, was realized in the case of Bajic's opera Knez Ivo od Semberije (Prince Ivo of Semberija; edited, re-orchestrated, and conducted by Predrag Milošević with the opera ensemble of the National Theatre in Belgrade) and stage works by Krešimir Baranovic performed by the Belgrade Philharmonic Orchestra led by the author, who served as the national orchestra's conductor for a number of years. ${ }^{31}$

The problem circle of musical heritage, its preservation, protection, and presentation in new contexts, acquired new guises by bringing two projects together, Anthological Pieces of Serbian Music and Tragom zapisa i zvuka (Following Recordings and Sounds), in the context of two modernist ballets and an opera, in collaboration with the Madlenianum, a privately owned theatre and opera house in Belgrade. The two ballets are Sobareva metla (The Servant's Besom, 1923) with music by Miloje Milojević, a setting of a surrealist libretto by Marko Ristić, and Balada o mesecu lutalici (The Ballad of the Vagabond Moon, 1957), a burlesque love dance in three scenes with music by Dušan Radić and libretto by Bora Cosić; though separated by a quarter century, the two ballets are brought together by their modernistically compressed forms and provocative expression, constituting two "radical leaps in the history of Serbian art music [which have] over time earned the epithet of anthological". ${ }^{32}$ Both ballets were premièred at the Madlenianum on 10 April 2012, with a new take, from the perspective of our time, on the musical conceptions of their respective authors from the early and mid $20^{\text {th }}$ century, in terms of choreography and directing (Aleksandar Saša Ilić),

\footnotetext{
${ }^{31}$ At this time, there is an ongoing project to produce a digitized and musicological presentation of Nikola Hercigonja's stage-music vision Planetarijom, the only existing recording of which was made by Radio Television Belgrade Symphony Orchestra, conducted by Borivoj Simić.

32 Vesna Mikić, introductory note in scores: Miloje Milojević, Sobareva metla and Dušan Radić, Balada o mesecu lutalici, Belgrade, Serbian Musicological Society, 2013.
} 
stage set and costume design (Snežana Arnautović). The following year, these new visual and stage versions of the anthological ballets of Milojević and Radić were complemented with an electronic edition of their scores, which completed the cycle of research from "sound to recording" and opened the way for new interpretations of these important works, both on stage and in musicology.

Carried forward by these successful and favourably received editions, with an enhanced visibility and self-respect, in 2013, acting on an initiative of Dr Branka Radović, the Society embarked on what was its thus far most complex and ambitious project, once again combining two of its proven formulae, already tested in Anthological Pieces of Serbian Music and Tragom zapisa i zvu$k a$. This project concerns a complete reconstruction of Suton (The Twilight), an opera by Stevan Hristić, from his manuscripts to staging, written in 1925 as a setting of the eponymous play by Ivo Vojnović; the reconstruction involved a professional and authorial team of music experts and connoisseurs of Hristić's oeuvre (including musicologists, theatre scholars, transcribers, theatre directors, opera and ballet ensembles, stage set and costume designers of the Madlenianum Opera and Theatre, proceeding through a number of stages. Upon the completion of an electronic copy, a scholarly edited and corrected version of the only existing version of the piece, along with the Ballet Divertissement, which was added later, and a vocal score of the opera, the second stage involved the preparation of the publication entitled Pred Sutonom Vojnovića i Hristića (Facing the Twilight of Vojnović and Hristić) and the translation of the libretto from the old Dubrovnik dialect of Vojnovic to Serbian and English, and the writing of three pre-commissioned studies, a theatre study and three original studies exploring, from different perspectives, Vojnović's literary template, the stylistic coordinates and structure of the opera Suton, as well as the little known Ballet Divertissement. ${ }^{33}$ The final stage of the project included the translation of those texts into English and staging the opera, directed by Nebojša Bradić and conducted by Vesna Šouc. The première of this opera, which had been staged only three times before, occurred on 22 October 2016 at Bemus, ${ }^{34}$ while the bilingual publication was promoted at the reprise, whereby this project of the Serbian Musicological Society, the most ambitious so far, was completed.

This outline of the central achievements of the Society's scholarly and publishing activities from its first decade should also include electronic editions of

\footnotetext{
33 The studies were authored by Raško B. Jovanović, Dr Tijana Popović Mlađenović, Dr Marja Masnokosa, and Dr Branka Radović. The production of the electronic copy was entrusted to the conductor Miodrag Janoski.

34 IIped Cymonon Bojnosuha u Xpucmuha / Facing the Twilight by Vojnović and Hrisitic, Београд, Madlenianum, Музиколошко друштво Србије, 2016.
} 
Kotevska, A., Serbian Musicological Society at the Beginning of its Second Decade

Josip Slavenski's choral music, ${ }^{35}$ produced on the occasion of the $120^{\text {th }}$ anniversary of the composer's birth and conceived as the resumption of the joint venture of the Composers' Association of Serbia and the Croatian Composers' Society to publish the composer's complete works, abandoned in 1990, on the eve of the breakup of Yugoslavia. In an effort to ensure that this publishing venture was not left without a life in sound, too, it envisages a concert series that will present, complete with informative lectures, a segment of Slavenski's choral works to a wider audience in Serbia and Croatia and thus at least begin to open the closed pathways of communication between the two countries. ${ }^{36}$

Seeking to continue its cultural mission, the Society is embarking on its second decade with new projects, expecting more in terms of social and financial support. One of these projects is another international scholarly meeting, conceived to mark the anniversary of the deaths of Petar Krstić (1877-1957), Petar Stojanović (1877-1957), and Stanislav Binički (1872-1942), three composers whose activities and significance have yet to be fully explored. ${ }^{37}$

"The thematic framework of this scholarly meeting was stimulated by the dynamic changes in musicology, suggesting a critical re-examination of canonized musical values, pointing to previously neglected aspects of musical culture, broaching questions about alternative conceptualizations of music history, and affirming the advantage of studying music as a formative factor in the making of a socio-historical context."

Formulated along these lines, the call for papers written by Biljana Milanović, who initiated the conference, attracted 25 participants, including 11 from abroad, who study the three composers in the context of Austria-Hungary and the Kingdom of Serbs, Croats, and Slovenes/Yugoslavia.

$* * *$

To put it in numbers, over the past ten years, either independently or in collaboration with related institutions, the Serbian Musicological Society organized and held three national and four international scholarly meetings; edited and pub-

35 Josip Slavenski, Mešoviti horovi [Mixed Choruses], Beograd, Muzikološko društvo Srbije, 2016; Josip Slavenski. Muški, ženski i dečji horovi [Men's, Women's, and Children's Choruses], Beograd, Muzikološko društvo Srbije, 2017.

${ }^{36}$ The first concert lecture is scheduled for the end of December 2017, as part of the Choirs among Frescoes festival.

37 На маргинама музиколоиког канона: композиторска генерачија Петра Стојановића, Петра Крстића и Станислава Биничког / On the Margins of the Musical Canon: The Generation of Composers Petar Stojanović, Petar Krstić, and Stanislav Binički, 1-2 December 2017. 
lished six collections of essays, two of them bilingual (in Serbian and English), as well as a bilingual critical edition of a TV series the history of Serbian music; five electronic scores; four CDs; the Catalogue to the Legacy Library of Vlastimir Peričić... It initiated and made possible two productions of staged musical works, a ballet and an opera, and organized around ten concerts and promotions of its publications. Its numerous activities involved musicologists, ethnomusicologists, and theorists from Serbia (49) and abroad (31), seven experts from other fields, transcribers, and professional translators as authors, reviewers, editors, publishers, translators, and even visual artists and performers.

This analysis of what at first sight may seem an eclectic selection of projects, due to the Steering Committee's democratic decision-making about proposals coming from the Society's members, the implementation of which depends on their success at funding competitions, shows a scrupulous adherence to the aims stated in the Society's Statute, which are still, a full decade later, proving to be inspiring and relevant. The Society is entering its second decade at an accelerated pace, aware of the challenges of a new era and a dynamic and variable musicological scene, which call for increasingly urgent reactions to contemporary trends and new considerations of the past.

\section{Summary}

The $10^{\text {th }}$ anniversary of the founding of the Serbian Musicological Society (SMS) was the occasion for compiling this initial body of material for future research. The text examines the reasons for the delay in the establishment of the Society and presents its accomplishments so far, which cannot be viewed in isolation from contemporary trends in new musicology and critical re-examinations of established views of the musical past. To quantify this, over the course of its first decade, the Society, which comprises around 50 members, independently and in collaboration with related scholarly and educational institutions (Department of Musicology at the Faculty of Music, Institute of Musicology at the Serbian Academy of Sciences and Arts, Josip Slavenski School of Music), music organizations (Musical Youth of Belgrade), the public broadcasting service (Serbian Broadcasting Corporation Publishing), and theatres (the privately owned Madlenianum Theatre and Opera House), has conceived and organized three national and two international scholarly meetings, edited and published six essay collections, five electronic scores, four CDs, two DVDs, a Catalogue to the Legacy Library of Vlastimir Peričić, entrusted to the Society for safekeeping... In line with the title of two of its projects, Anthological Pieces of Serbian Music and Following Recordings and Sounds, the Society has organized around a dozen concerts and concert lectures. The text sheds special light on the Society's longterm projects, which have enabled, through the complex process of working on musical scores, the revival of two forgotten modernist ballets by Miloje Milojević (Sobareva metla / The Servant's Besom) and Dušan Radić (Balada o mesecu lutalici / The Ballad of the 
Kotevska, A., Serbian Musicological Society at the Beginning of its Second Decade

Vagabond Moon) and an opera by Stevan Hristić (Suton / The Twilight), the first Serbian opera without a libretto based on national history or folklore. The Serbian Musicological Society is entering its second decade with a rejuvenated membership and new projects, which may indicate the further development and promotion of musicological creativity not only in Serbia but also internationally, closer connections with musicologists from the region, and more substantial social and financial support to enable such aspirations. 